\title{
Microwave-assisted Synthesis of Green Inhibitor for Carbon Steel Acid Corrosion
}

\author{
Sami Ben Aoun ${ }^{*}$ and Mouslim Messali \\ Department of Chemistry, Faculty of Science, Taibah University, PO. Box 30002 Al-Madinah Al- \\ Munawarah, KSA. \\ *E-mail: sbenaoun@taibahu.edu.sa
}

doi: $10.20964 / 2018.04 .55$

Received: 27 December 2017 / Accepted: 10 February 2018 / Published: 6 March 2018

\begin{abstract}
1-(3-bromopropyl)-4-(dimethylamino)pyridinium bromide (DPB) ionic liquid prepared via microwave-assisted synthesis was investigated as a potential corrosion inhibitor for carbon steel in molar hydrochloric acid solution by means of weight-loss method. The obtained results revealed the high inhibitive activity of the prepared ionic liquid with increasing inhibition efficiency reaching ca. $87.1 \%$ in the presence of $3 \times 10^{-3} \mathrm{M}$ DPB. The adsorptive nature of the inhibition process was proven by kinetics and thermodynamics investigations with a large adsorption constant $\left(\mathrm{K}_{\mathrm{ads}}=\mathrm{ca} .3 .8 \times 10^{3} \mathrm{~mol}^{-}\right.$ $\left.{ }^{1} . \mathrm{L}\right)$ and an elevated activation energy $\left(\mathrm{E}_{\mathrm{a}}=\mathrm{ca} .83 .1 \mathrm{~kJ}^{\mathrm{mol}}{ }^{-1}\right)$. DPB was found to show a predominant physical adsorption onto the corroding carbon steel surface $\left(\Delta \mathrm{G}_{\mathrm{ads}}=\right.$ ca. $\left.-35.9 \mathrm{~kJ} \cdot \mathrm{mol}^{-1}\right)$. Electrochemical investigations revealed that DPB acted as a mixed-type corrosion inhibitor hindering both anodic and cathodic processes via blocking their respective active sites. The inhibitor was shown to form a protective layer resulting in increasing charge transfer resistance along with a decreasing double layer capacitance.
\end{abstract}

Keywords: Carbon steel; Corrosion; Ionic liquids; Gravimetric method; Langmuir isotherm; LPR; EIS.

\section{FULL TEXT}

(C) 2018 The Authors. Published by ESG (www.electrochemsci.org). This article is an open access article distributed under the terms and conditions of the Creative Commons Attribution license (http://creativecommons.org/licenses/by/4.0/). 